is physically distinct from ribosomal or soluble (transfer) RNA. 'This fraction behaves, in its range of sedimentation constants and its attachment to ribosomes in high magnesium ion concentrations, exactly as does the phage-specific RNA made after T2 infection. Furthermore, it is associated with the active $70 \mathrm{~s}$ ribosomes, the site of protein synthesis.

Our working hypothesis is that no fundamental difference exists between protein synthesis in phageinfected and uninfected bacteria. In both cases typical ribosomal RNA does not carry genetic information, but has another function, perhaps to provide a stable surface on which transfer RNA's can bring their specific amino-acids to the messenger RNA template.

These experiments were initiated when F. Gros was visiting the Biological Laboratories (MayAugust 1960). The pyrimidine-requiring strain $B 148$ was kindly provided by Dr. Martin Lubin. The financial support of the National Science Foundation and the National Institutes of Health is gratefully appreciated.

${ }^{3}$ Cohen, S. S., Bact. Rev., 13, 1 (1949). ${ }^{2}$ Koch, G., and Hershey, A. D., J. Mol. Biol., 1, 260 (1959), KornU.S. Nat. Acad. Sci., 45, 772 (1959).

${ }^{3}$ Cohen, S. S., J. Biol. Chem., 174, 271 (1948)

4 Hershey, A. D., Dixon, J., and Chase, M., J. Gen. Physiol., 36, 777 (1953).

'Volkin, E., and Astrachan, L., Virology, 2, 149 (1956).

'Volkin, E., Astrachan, L., and Countryman, J. L., Virology, 6, 545 (1958).

7 Zamecnik, P. Z., The Harvey Lectures (1958-59), 256 (Academic Press, New York, 1960).

${ }^{8}$ Crick, F. H. C., Brookhaven Symposia in Biology, 12, Structure and Function of Genetic Flements, 35 (1959).

' Nomura, M., Hall, B. D., and Spiegelman, S., J. Mol. Biol., 2, 306 (1960).

${ }^{10}$ Jacob, F., and Monod, J., J. Mol. Biol. (in the press)

11 Tissières, A., Watson, J. D., Schlessinger, D., and Hollingworth, B. R., J. Mol. Biol., 1, 221 (1959).

12 Kurland, C. G., J. Mol. Biol., 2, 83 (1960).

${ }^{13}$ Berg, P., and Ofengand, E. J., Proc. U.S. Nat. Acad. Sci., 44, 78 (1958). Tissières, A., J. Mol. Biol., 1, 365 (1959)

14 MeQuillen, K., Roberts, R. B., and Britten, R. J., Proc. U.S. Nat. Acad. Sci., 45, 1437 (1959).

${ }^{15}$ Grunberg-Manogo, M., Ortiz, P. J., and Ochoa, S., Science, 122, 907 (1955).

${ }^{16}$ Elson, D., Biochim. Biophys. Acta, 27, 217 (1958). Spahr, P. F., and Hollingworth, B., $J$. Biol. Chem. (in the press).

17 Spahr, P. F., and Tissières, A., J. Mol. Biol., 1, 237 (1959).

${ }^{18}$ YCas, M., and Vincent, W. S., Proc. U.S. Nat. Acad. Sci., 46, 804 $(1960)$.

10 Tissières, A., Schlessinger, D., and Gros, Françoise, Proc. V.S. Nat. Acad. Sci., 46, $1450(1960)$.

\title{
DR. W. H. FITTON, F.R.S.
}

\author{
By JOAN M. EYLES
}

$\mathrm{W}$ ILLTAM HENRY FITTON, physician and geologist, died in London on May 13, 1861, at the age of eighty-one. In an obituary notice, Sir Roderick Murchison, director-general of the Geological Survey, described him as "truly one of the British worthies who have raised modern geology to its present advanced position".

Fitton, of English descent, was born and brought up in Dublin and his proficiency in the classics enabled him to gain, in 1798, the Senior Scholarship of Trinity College. Even then he was a fossil collector, a hobby which brought him into the hands of the military on suspicion of being a rebel. In 1808 , he went to Edinburgh to study medicine, and there attended the geological lectures of Robert Jameson, who was responsible for stimulating an interest in science and natural history in many young men at that time. Fitton graduated M.D. at Edinburgh in 1810, but continued to study medicine and chemistry in London until 1812. In that year he moved to Northampton, where he was in practice until 1820 . Then marriage to a lady of considerable means enabled him to give up his practice and return to London, where his house soon became a regular meeting place for men of science and, in particular, geologists.

Fitton did not become a Follow of the Ceological Society until 1816, but his first geological paper, "On the Geological Structure of the Vieinity of Dublin", appeared in 1811 in the first volume of the Society's Transactions. In 1817 he contributed to the Edinburgh Review the first of a number of reviews, often lengthy, of geological works, which are noteworthy for the valuable information they contain on the history and progress of geology. These may still be consulted with profit by the historian of geology, for Fitton was widely read, had a clear analytical mind, and wrote with the facility of a classical scholar. Secretary of the Geological Society during 1822-24, he was elected president in 1827, and during his term of office introduced an important innovation, the publication of the Proceedings of the Society, of which the first number appeared in April 1827. In this publication the presidential addresses were published, Fitton's being the first to appear, and thus began that valuable annual series in which for many years the progress of geology was reviewed. Fitton was also instrumental in appointing, as curator and librarian, in 1829, William Lonsdale, a gifted palæontologist, who served the Society until 1842 .

The geological work for which Fitton is best remembered, however, is his elucidation of the stratigraphy of the beds lying between the Kimmeridge Clay and the Chalk, that is, of the upper part of the Jurassic and the Lower Cretaceous. The succession comprises limestones, clays and sandstones, some marine and some fresh-water. During the course of a prolonged study of these beds in both the south-east of England and north-east France, he was able to establish the correct order of succession, a major advance in British stratigraphy. For these researches he received the Wollaston Medal of the Geological Society in 1852 .

Fitton was elected Fellow of the Royal Society in 1815, and was also Fellow of the Linnean, Astronomical and Royal Geographical Societies. 